\title{
Comparative Investigation of Microbial Communities Associated with Hydrothermal Activities in the Okinawa Trough
}

\author{
Ken Takai, Satoshi Nakagawa, and Takuro Nunoura
}

\begin{abstract}
In the Okinawa Trough, microbial communities in deep-sea hydrothermal vent chimneys have been extensively studied in the Iheya North (Iheya North Knoll) and the Yonaguni Knoll IV (Daiyon-Yonaguni Knoll) fields. In comparison of the microbial community patterns in geographically and geologically diverse deep-sea hydrothermal systems all the world, the Okinawa Trough deep-sea vent microbial communities have been known to be distinctive and to be associated with the unique hydrothermal fluid chemistry commonly observed in the Okinawa Trough systems. However, this implication is based only on the data from the above two hydrothermal systems. Here, we further show the microbial community patterns of Minami-Ensei (Minami-Ensei Knoll), Izena Hole Jade and Hakurei fields in the Okinawa Trough, using data by culture-dependent techniques. The comparison of the microbial community patterns determined in typical chimney habitats of representative Okinawa Trough hydrothermal systems including new data points that the diversity and abundance of cultivated microbial populations are significantly relevant with intra-field variation of hydrothermal fluid chemistry induced by the subseafloor phaseseparation and -partition processes rather than with inter-fields variability in the endmember fluid chemistry. Inter-fields variability in potential microbial community development in the Okinawa Trough hydrothermal systems may be caused by other possible bases in the microbial community development such as the physical mode of hydrothermal fluid discharges, the age of hydrothermal system and the hydrogeological complexity of subseafloor hydrothermal fluid flow structures. Nevertheless, the correlation between the $\mathrm{H}_{2}$ concentration in hydrothermal fluid and the culturable population size of
\end{abstract}

K. Takai $(\bowtie)$

Department of Subsurface Geobiological Analysis and Research (D-SUGAR) and Research and Development (R\&D) Center for Submarine Resources, Japan Agency for Marine-Earth Science and Technology (JAMSTEC), 2-15 Natsushima-cho,

Yokosuka 237-0061, Japan

e-mail: kent@jamstec.go.jp

S. Nakagawa

Department of Subsurface Geobiological Analysis and Research (D-SUGAR), Japan Agency for Marine-Earth Science and Technology

(JAMSTEC), 2-15 Natsushima-cho, Yokosuka 237-0061, Japan

Division of Applied Biosciences, Graduate School of Agriculture, Kyoto University, 3-1-1 Minato-cho, Hakodate,

Hokkaido 041-8611, Japan

T. Nunoura

Research and Development Center for Marine Biosciences, Japan Agency for Marine-Earth Science and Technology (JAMSTEC), 2-15 Natsushima-cho, Yokosuka 237-0061, Japan 
$\mathrm{H}_{2}$-trophic methanogens is reinforced by the new results obtained from the Izena Hole Hakurei chimney habitat hosting the $\mathrm{H}_{2}$-enriched hydrothermal fluid. It seems very likely that the $\mathrm{H}_{2}$ concentration in the hydrothermal fluid is still a very important chemical factor to control the chemolithotrophic microbial community development essentially in the global deep-sea hydrothermal systems.

Keywords

Chemolithoautotroph $\bullet$ Deep-sea hydrothermal vents $•$ Epsilonproteobacteria $\bullet$ Methane • Okinawa Trough

\subsection{Introduction}

Deep-sea hydrothermal vent environments represent one of the most physically and chemically diverse biomes in Earth. The chemical and thermal gradients provide a wide range of niches for microbial communities living there (Huber and Holden 2008; Nakagawa and Takai 2008; Nakamura and Takai 2014; Reysenbach et al. 2000; Takai et al. 2006; Takai and Nakamura 2010, 2011). Phylogenetically and physiologically diverse microorganisms thrive by chemolithoautotrophy or heterotrophy, utilizing abundant available inorganic and organic chemical energy, carbon and other element sources. They reside as free-living and biofilm-forming lifestyles in the rocky and sedimentary mixing interfaces between hot, highly reductive hydrothermal fluids (high-temperature endmember hydrothermal fluids) and ambient seawaters beneath and at the seafloor and within the lower-temperature diffuse fluids mainly resulting from subseafloor mixing between endmember hydrothermal fluids and ambient seawaters, and as facultative or obligate symbiotic lifestyle on and within the invertebrate hosts (Nakamura and Takai 2014; Takai et al. 2006; Takai and Nakamura 2010, 2011).

Over the past two decades, microbiologists have gained significant insights into the compositional and functional diversity of microbial communities in these unique ecosystems. In particular, the microbial communities have been extensively explored in the chimney structures and using the artificial habitats (e.g., in situ colonization devices) associated with high-temperature endmember-like hydrothermal fluid discharges (Takai et al. 2006; Takai and Nakamura 2010, 2011). The early research was conducted in the several deep-sea hydrothermal systems in the Mid Ocean Ridges (MORs), however recently, as the greater heterogeneity of the physical and chemical characteristics of hydrothermal fluids in the Volcanic Arcs (VAs) and Backarc Basins (BABs) and even of hydrothermal fluids in the ultramafic rocks-associated systems recently found in the MORs, many studies have demonstrated the great interfields heterogeneity of the microbial communities, particularly present in the chimney structures among a variety of fields (Nakamura and Takai 2014; Takai et al. 2006; Takai and Nakamura 2010, 2011). These results have suggested the impact of endmember-like hydrothermal fluid chemistry on the compositions and functions of proximal microbial communities in the subseafloor as well as at the seafloor habitats including chimneys. In addition, several disciplines of approaches begin to clarify the geochemicalmicrobial interrelation based on the thermodynamic modeling of microbially available energy potentials by various chemolithotrophic metabolisms in the hydrothermal mixing zones and the inter-fields comparisons of functionally active microbial communities coupled with hydrothermal inputs of energy sources (McCollom 2007; McCollom and Shock 1997; Nakamura and Takai 2014; Shock and Holland 2004; Takai and Nakamura 2010, 2011; Nakamura and Takai Chap. 2).

The thermodynamic calculations have clearly predicted that the hydrothermal fluid chemistry variation leads to different patters and compositions of chemolithotrophic microbial communities, particularly in chimney habitats (Nakamura and Takai 2014; Takai and Nakamura 2010, 2011). In the model, the S-trophic (thiotrophic) chemolithotrophy would be always predominant in any types of deep-sea hydrothermal systems while the $\mathrm{H}_{2}$-trophic (hydrogenotrophic) methanogenesis, $\mathrm{SO}_{4}$-reduction and S-reduction should be fostered particularly in high temperature zones of $\mathrm{H}_{2}$-enriched deep-sea hydrothermal systems (Nakamura and Takai 2014; Takai and Nakamura 2010, 2011). These predictions are indeed supported by the estimated population abundances of the $\mathrm{S}$-trophic and $\mathrm{H}_{2}$ trophic chemolithotrophs using quantitative cultivation analyses (Nakamura and Takai 2014; Takai and Nakamura 2010, 2011). In addition, the thermodynamic model have pointed to unique composition of chemolithotrophic microbial communities that would be driven by psychrophilic to hyperthermophilic aerobic methanotrophs and ammoniaoxidizers and hyperthermophilic anoxic methanotrophs in the Okinawa Trough deep-sea hydrothermal systems (Nakamura and Takai 2014; Takai and Nakamura 2010, 
2011). Although the microbiological characterizations have not fully justified the formation of unique chemolithotrophic communities in the Okinawa Trough deep-sea hydrothermal systems, the development of a great phylogenetic and physiological diversity of chemolithotrophic microbial communities has been demonstrated by the previous cultivation-dependent and even the molecular ecological methods (Nakagawa et al. 2005; Nunoura and Takai 2009; Takai et al. 2006). However, these implications have been based only on the results of microbiological characterizations in two hydrothermal systems, Iheya North (Iheya North Knoll) and Yonaguni Knoll IV (Daiyon-Yonaguni Knoll) fields of the Okinawa Trough.

The Okinawa Trough is a "rifting phase" of Backarc Basin covered with thick terrigenous sediments (Letouzey and Kimura 1986) and is now known to host seven active deep-sea hydrothermal fields, of which the seafloor hydrothermal activities have been verified by the seafloor observation and the hydrothermal fluid and mineral samples have been investigated (Glasby and Notsu 2003; Ishibashi et al. Chap. 27). The Izena Hole Jade and Hakurei fields and the Iheya Ridge Clam field were discovered in the late 1980s, the Minami-Ensei (Minami-Ensei Knoll) field in 1990, the Iheya North field in 1995, and finally the Yonaguni Knoll IV field and the Hatoma Knoll fields were explored in 1999 (Glasby and Notsu 2003; Ishibashi et al. Chap. 27). Since the discovery of these Okinawa Trough hydrothermal systems, more than 300 dives of manned submersibles and remotely operative vehicles have been organized, and the geochemical analyses of hydrothermal fluids and mineral deposits and the microbiological characterizations have been extensively conducted (Glasby and Notsu 2003; Ishibashi et al. Chap. 27). At present, the detail physical and chemical characteristics of hydrothermal fluids have been determined in the Iheya North field (Kawagucci et al. 2011), the Yonaguni Knoll IV field (Konno et al. 2006; Suzuki et al. 2008), the Minami-Ensei field (Kawagucci et al. 2013) and the Izena Hole Jade and Hakurei fields (Ishibashi et al. 2014; some data summarized in Kawagucci Chap. 30). Thus, if the compositions and functions of microbial communities in the chimney habitats are characterized with a combination of the detail physical and chemical characteristics of the proximal hydrothermal fluids, the new data provide important insights into understanding the inter-fields and intra-field features of microbial community development patterns and geochemical-microbial interrelation in the Okinawa Trough hydrothermal systems. In this chapter, we show the microbial community patterns in the chimney habitats characterized mainly by using culture-dependent techniques in the Minami-Ensei, Izena Hole Jade and Hakurei fields of the Okinawa Trough. The overall comparison of the microbial community patterns points to the conventional and unique aspects of the geochemical-microbial interrelation in the Okinawa Trough hydrothermal systems.

\subsection{Materials and Methods}

\subsubsection{Site Summary, Seafloor Sampling and Onboard Processes}

For Jade and Hakurei fields of the Izena Hole, all samples used in this study were obtained by means of a manned submersible Shinkai 2000 and its mother research vessel Natsushima in the cruise of August 2003 (JAMSTEC cruise NT03-08). Bulks of chimney structures (>100 g) were obtained from high-temperature hydrothermal fluid discharge vent sites (TBS chimney site at the Jade field and 214 chimney site at the Hakurei field). For the Minami-Ensei (Minami-Ensei Knoll) field, all samples used in this study were obtained by a remotely operative vehicle (ROV) Hyper Dolphin and its mother research vessel Natsushima in the cruise of July 2007 (JAMSTEC cruise NT07-11). In both cruises, the obtained hydrothermal fluids were investigated by onboard and onshore measurements, sample preparations and geochemical analyses, and the detail physical and chemical properties of the high-temperature and the endmember hydrothermal fluids were reported in the previous studies (Table 32.1) (Ishibashi et al. 2014; Kawagucci et al. 2013).

The chimney structures examined in this study were TBS chimney at the Izena Hole Jade field, 214 chimney at the Izena Hole Hakurei field, and Jizo and No. 7 chimneys at the Minami-Ensei field (Table 32.1). Each of the recovered chimney samples was further divided and subjected to nucleic acid extraction, microscopic observation and liquid serial dilution culture as previously reported by Nakagawa et al. (2005) and Nunoura and Takai (2009). For liquid serial dilution culture experiments, the subsamples of the chimneys (about $10 \mathrm{~g}$ wet weight) were slurried with sterile MJ synthetic seawater (30 mL) (Takai et al. 1999) containing neutralized $\mathrm{Na}_{2} \mathrm{~S}$ solution at a final concentration of $0.05 \%$ (wt/vol) under $\mathrm{N}_{2}$ atmosphere, and stored at $4{ }^{\circ} \mathrm{C}$ in the dark until they were used. For microscopic observation, the subsamples (about $2 \mathrm{~g}$ ) were fixed with sterile MJ synthetic seawater $(10 \mathrm{~mL})$ containing $3.7 \%(\mathrm{wt} / \mathrm{vol})$ of formaldehyde for $24 \mathrm{~h}$ and then stored at $-80{ }^{\circ} \mathrm{C}$. The remaining subsamples were stored at $-80{ }^{\circ} \mathrm{C}$ for nucleic acid extraction.

In the Izena Hole Hakurei field, an in situ colonization system (ISCS) (Takai et al. 2003; Nakagawa et al. 2005) was deployed for 5 days in the vent orifice of the 214 chimney that hosted high-temperature hydrothermal fluid. After 5 days incubation, the ISCS was recovered onboard and the substratum was subsampled for the nucleic acid extraction, 
Table 32.1 Physical and chemical characteristics of hydrothermal fluids in different deep-sea hydrothermal fields of Okinawa Trough

\begin{tabular}{|c|c|c|c|c|c|c|c|c|c|c|}
\hline Field & Iheya North & & & Yonaguni & Knoll IV & $\begin{array}{l}\text { Izena Hole } \\
\text { Jade }\end{array}$ & $\begin{array}{l}\text { Izena Hole } \\
\text { Hakurei }\end{array}$ & Minami-Ense & & Ambient \\
\hline Vent site & $\mathrm{NBC}$ & $\mathrm{CBC}$ & E18 & BTC & CTC & TBS & 214 & Jizo & No. 7 & seawater \\
\hline $\begin{array}{l}\text { Temp. } \\
\left({ }^{\circ} \mathrm{C}\right)\end{array}$ & 311 & 311 & 311 & 330 & 330 & 320 & 326 & 280 & 280 & 2 \\
\hline $\begin{array}{l}\text { Depth } \\
\text { (m) }\end{array}$ & 980 & 990 & 1,000 & 1,369 & 1,362 & 1,340 & 1,600 & 710 & 722 & \\
\hline $\mathrm{pH}$ & 4.8 & 5.3 & $4.6^{\mathrm{a}}$ & $5.3^{\mathrm{b}}$ & $4.7^{\mathrm{a}}$ & 4.7 & 4.7 & 4.9 & 4.9 & 7.8 \\
\hline $\mathrm{H}_{2}(\mathrm{mM})$ & 0.229 & $0.135^{\mathrm{c}}$ & $0.346^{\mathrm{c}}$ & 0.8 & 2.4 & 0.06 & 1.4 & 0.029 & 0.033 & 0.0000004 \\
\hline $\begin{array}{l}\mathrm{H}_{2} \mathrm{~S} \\
(\mathrm{mM})\end{array}$ & 4.5 & $2.7^{\mathrm{c}}$ & $6.8^{c}$ & $19.7^{\mathrm{a}}$ & $38.3^{\mathrm{a}}$ & 5.6 & 5.3 & 0.40 & $0.92^{\mathrm{a}}$ & 0 \\
\hline $\begin{array}{l}\mathrm{CH}_{4} \\
(\mathrm{mM})\end{array}$ & 3.7 & $2.2^{\mathrm{c}}$ & $5.6^{\mathrm{c}}$ & 1.8 & 9.1 & 4.9 & 5.8 & 2.3 & 2.6 & 0.0000003 \\
\hline $\begin{array}{l}\mathrm{CO}_{2} \\
(\mathrm{mM})\end{array}$ & 230 & $136^{\mathrm{c}}$ & $347^{\mathrm{c}}$ & 71 & 318 & 156 & 151 & 39 & 46 & 2.3 \\
\hline $\mathrm{N}_{2}(\mathrm{mM})$ & $0.0346^{\mathrm{b}}$ & $0.0189^{c}$ & $0.0487^{\mathrm{c}}$ & $1.5^{\mathrm{a}}$ & $2.0^{\mathrm{a}}$ & $1.5^{\mathrm{a}}$ & $1.5^{\mathrm{a}}$ & 0.35 & 2.2 & 0.59 \\
\hline $\mathrm{CO}(\mathrm{mM})$ & $<0.0001^{\mathrm{b}}$ & $<0.0001^{\mathrm{b}}$ & $<0.0001^{\mathrm{b}}$ & $<0.0001^{\mathrm{a}}$ & $<0.0001^{\mathrm{a}}$ & 0.03 & 0.063 & $<0.0001^{\mathrm{b}}$ & $<0.0001^{\mathrm{b}}$ & 0 \\
\hline $\begin{array}{l}\mathrm{SO}_{4} \\
(\mathrm{mM})\end{array}$ & 0 & 0 & 0 & 0 & -1.6 & 0 & 0 & 0 & 0 & 27.9 \\
\hline $\begin{array}{l}\mathrm{NH}_{4} \\
(\mathrm{mM})\end{array}$ & 1.7 & $1.85^{\mathrm{b}}$ & 1.85 & 8.6 & 20.7 & 4.2 & 4.4 & 5.4 & 5.4 & 0.00005 \\
\hline $\mathrm{Na}(\mathrm{mM})$ & 432 & 745 & 288 & 433 & 254 & 442 & 458 & 436 & 436 & 464 \\
\hline $\mathrm{Cl}(\mathrm{mM})$ & 544 & 864 & 338 & 635 & 376 & 590 & 608 & 562 & 562 & 546 \\
\hline $\mathrm{Ca}(\mathrm{mM})$ & 16.1 & 19.9 & 11.9 & 26.1 & 14.3 & 22 & 23 & 23 & 23 & 10.2 \\
\hline $\mathrm{Mg}(\mathrm{mM})$ & 0 & 0 & 0 & 0 & 0 & 0 & 0 & 0 & 0 & 52.7 \\
\hline $\mathrm{K}(\mathrm{mM})$ & 72 & 79 & 56.2 & 90.1 & 55.3 & 72 & 75 & 53 & 53 & 9.8 \\
\hline $\mathrm{Fe}(\mathrm{mM})$ & $0.251^{\mathrm{b}}$ & $0.424^{c}$ & $0.167^{\mathrm{c}}$ & 0.2 & 0.1 & 0.031 & 0.445 & $<0.12$ & $<0.12$ & 0.0000015 \\
\hline $\mathrm{Mn}(\mathrm{mM})$ & 0.619 & 0.46 & 0.445 & 1.25 & 0.7 & 0.341 & 0.29 & 0.099 & 0.099 & 0 \\
\hline $\begin{array}{l}\mathrm{NO}_{3} \\
(\mathrm{mM})\end{array}$ & 0 & 0 & 0 & 0 & 0 & 0 & 0 & 0 & 0 & 0.03 \\
\hline $\mathrm{Si}(\mathrm{mM})$ & 10.1 & 11.6 & 6.9 & 13.2 & 12.5 & 11.8 & 11.3 & 11.1 & 11.1 & 0.16 \\
\hline$\delta \mathrm{D}\left(\mathrm{H}_{2}\right)$ & -430 & n.d. & n.d. & n.d. & n.d. & -381 & -379 & -642 & -405 & \\
\hline $\begin{array}{l}\delta^{13} \mathrm{C} \\
\left(\mathrm{CO}_{2}\right)\end{array}$ & -9.7 & n.d. & n.d. & -7.6 & -7.6 & -6.2 & -6.2 & -5.0 & -5.3 & \\
\hline $\begin{array}{l}\delta^{13} \mathrm{C} \\
\left(\mathrm{CH}_{4}\right)\end{array}$ & -53.8 & n.d. & n.d. & -25.9 & -26.6 & -30.8 & -32.1 & -25.1 & -25.3 & \\
\hline $\begin{array}{l}\delta^{34} \mathrm{~S} \\
\left(\mathrm{H}_{2} \mathrm{~S}\right)\end{array}$ & $+12^{\mathrm{b}}$ & n.d. & n.d. & n.d. & n.d. & $+3.8 \sim+8.0$ & $+5.5 \sim+7.8$ & +3.6 & +3.6 & \\
\hline \multirow[t]{2}{*}{ Reference } & $\begin{array}{l}\text { Kawagucci } \\
\text { et al. (2011) }\end{array}$ & $\begin{array}{l}\text { Kawagucci } \\
\text { et al. (2011) }\end{array}$ & $\begin{array}{l}\text { Kawagucci } \\
\text { et al. (2011) }\end{array}$ & $\begin{array}{l}\text { Suzuki } \\
\text { et al. } \\
(2008)\end{array}$ & $\begin{array}{l}\text { Suzuki } \\
\text { et al. } \\
(2008)\end{array}$ & $\begin{array}{l}\text { Ishibashi } \\
\text { et al. (2014) }\end{array}$ & $\begin{array}{l}\text { Ishibashi } \\
\text { et al. (2014) }\end{array}$ & \multirow[t]{2}{*}{$\begin{array}{l}\text { Kawagucci } \\
\text { et al. (2013) }\end{array}$} & \multirow[t]{2}{*}{$\begin{array}{l}\text { Kawagucci } \\
\text { et al. (2013) }\end{array}$} & \multirow[t]{2}{*}{$\begin{array}{l}\text { McCollom } \\
(2007)\end{array}$} \\
\hline & $\begin{array}{l}\text { Nakagawa } \\
\text { et al. }(2005)\end{array}$ & $\begin{array}{l}\text { Nakagawa } \\
\text { et al. (2005) }\end{array}$ & $\begin{array}{l}\text { Nakagawa } \\
\text { et al. }(2005)\end{array}$ & $\begin{array}{l}\text { Konno } \\
\text { et al. } \\
\text { (2006) }\end{array}$ & $\begin{array}{l}\text { Konno } \\
\text { et al. } \\
\text { (2006) }\end{array}$ & $\begin{array}{l}\text { Kawagucci } \\
\text { (Chap. 30) }\end{array}$ & $\begin{array}{l}\text { Kawagucci } \\
\text { (Chap. 30) }\end{array}$ & & & \\
\hline
\end{tabular}

\footnotetext{
${ }^{\mathrm{b}}$ Unpublished data
}

${ }^{a}$ Values taken from a similar hydrothermal fluid: for E18 site in Iheya North field from a gas-rich fluid in the Yonaguni Knoll IV field (unpublished); for BTC and CTC in Yonoguni Knoll IV field from Cl-enriched and -depleted fluids in Hatoma Knoll field (unpublished); for Minami Ensei field (No. 7 site) from Minami Ensei field (Taimatsu site) (Kawagucci et al. 2013)

${ }^{c}$ Values calculated according to a simple phase-separation ratio that is linearly reproduced by the deviation of chloride concentrations in the hydrothermal fluids

n.d. not determined 
the microscopic observation and the liquid serial dilution culture as previously reported by Nakagawa et al. (2005).

\subsubsection{Total Direct Cell Counts}

Microbial cell densities in the sub-samples extracted from the chimney structures were determined by $4^{\prime}, 6$-diamidino2-phenylindole (DAPI)-staining direct counting. The thawed, formaldehyde-fixed chimney subsample was vigorously suspended with a vortex mixer. After $5 \mathrm{~min}$, $1 \mathrm{~mL}$ of formaldehyde-fixed supernatant was added to $1 \mathrm{~mL}$ of filter-sterilized phosphate-buffered saline (PBS, $\mathrm{pH}$ 7.2) containing DAPI $(10 \mu \mathrm{g} / \mathrm{mL})$, and incubated at room temperature for $30 \mathrm{~min}$. After the mixture was filtered, each filter was rinsed twice with $2 \mathrm{~mL}$ of filter-sterilized PBS. The filters were observed under epifluorescence using a phase-contrast Olympus BX51 microscope with the Olympus DP71 digital camera system. An average total cell count was obtained from more than 100 microscopic fields from three separate filters.

\subsubsection{Nucleic Acid Extraction and 16S rRNA Gene Clone Analysis}

Nucleic acids were extracted from the chimney outer surfaces and the chimney inside walls with the Ultra Clean Mega Soil DNA kit (MO Bio Laboratory, Solana Beach, CA, USA), following the manufacturer's instructions. A blank tube (with no sample added) was processed as a negative control. Extracted nucleic acids were stored at $-80^{\circ} \mathrm{C}$.

Bacterial and archaeal 16S rRNA genes were amplified from DNA extracts from subsamples and controls by PCR using LA Taq polymerase with GC buffer (TaKaRa, Kyoto, Japan). The oligonucleotide primers used were Bac27F and 1492R (Lane 1991) for the bacterial rRNA gene in the samples from both the Izena Hole and the Minami-Ensei fields, and Arch21F and Arch958R (DeLong 1992) in the cases of the Minami-Ensei field's samples, and Arch21F and $1492 \mathrm{R}$ in the cases of Izena Hole fields' samples. Thermal cycling was performed under the following conditions: $30-50$ cycles of $96{ }^{\circ} \mathrm{C}$ for $25 \mathrm{~s}, 50{ }^{\circ} \mathrm{C}$ for $45 \mathrm{~s}$ and $72{ }^{\circ} \mathrm{C}$ for $120 \mathrm{~s}$ for the archaeal $16 \mathrm{~S}$ rRNA gene and 20-40 cycles of $96{ }^{\circ} \mathrm{C}$ for $25 \mathrm{~s}, 54{ }^{\circ} \mathrm{C}$ for $45 \mathrm{~s}$ and $72{ }^{\circ} \mathrm{C}$ for $120 \mathrm{~s}$ for the bacterial 16S rRNA gene. The PCR cycle numbers represent almost the minimum cycle numbers providing enough amplified products for the cloning based on the preliminary PCR amplification experiments using the same templates. The amplified rRNA gene products from several separate reactions at the least number of thermal cycles were pooled and purified as previously described (Takai et al. 2001). Cloning and sequencing were also followed by the procedure described by Takai et al. (2001). The Bac27F (Lane 1991) or Arch21F (DeLong 1992) primer was used in partial sequencing analysis.

Single-strand sequences of approximately 500 nucleotides in length were determined. The sequence similarity was analyzed by the FASTA component program of DNASIS (Hitachi software, Tokyo, Japan). The rRNA gene sequences having $\geq 97 \%$ similarity by FASTA were assigned to the same phylotype. The partial sequences of the representative phylotypes were determined for both strands ( $>800 \mathrm{bp}$ ), and were applied to sequence similarity analysis against the non-redundant nucleotide sequence databases of GenBank, EMBL and DDBJ using the gapped-BLAST.

\subsubsection{Phylogenetic Analysis}

The sequences of the representative phylotypes from the clone analysis and the isolates were manually realigned according to the secondary structures using ARB (Ludwig et al. 2004). Phylogenetic analyses were restricted to nucleotide positions that could be chosen using the Bacteria and Archaea filters for the bacterial and archaeal 16S rRNA gene sequences (Hugenholtz 2002). Evolutionary distance matrix analysis (using the Jukes \& Cantor correlation method) and neighbor-joining analysis were performed using PHYLIP package (http://evolution.genetics.washington.edu/phylip. html). In this study, the phylogenetic analysis was conducted only to identify the phylogenetic affiliation of $16 \mathrm{~S}$ rRNA gene phylotypes and the isolated strains to the previously known phylogenetic groups, potentially corresponding to the appropriate phylum, order, family and genus levels of taxonomic hierarchy.

\subsubsection{Quantitative PCR Analysis}

Determination of the proportion of the archaeal 16S rRNA genes in the whole microbial DNA assemblage was performed by the quantitative fluorescent PCR method using TaqMan probes as described elsewhere (Takai and Horikoshi 2000). A dilution series of each of the DNA samples was prepared and the samples were assayed using the universal 16S rRNA gene mixture and the archaeal $16 \mathrm{~S}$ rRNA gene mixture as the respective standards (Takai and Horikoshi 2000).

\subsubsection{Liquid Serial Dilution Cultures}

To estimate the abundance of culturable microorganisms (viable counts) represented by a variety of physiological 
and metabolic characteristics, a series of serial dilution cultures were done from each of the chimney subsamples under the various cultivation conditions. All the cultivation experiments to estimate the viable counts were performed within 3 months after the sample collection. The cultivation experiments were conducted in the order of experiments for the strictly anaerobic chemolithoautotrophs, for the strictly anaerobic heterotrophs, for facultative anaerobic chemolithoautotrophs, for facultative anaerobic chemolithoautotrophs and for microaerobic chemolithoautotrophs. These conditions are also similar with those in the previous studies (Nakagawa et al. 2005; Nunoura and Takai 2009; Takai et al. 2008, 2009). In the cases of Izena Hole fields' samples, the media and the cultivation conditions for quantitative cultivation analysis were conducted in the same manner as described in Nakagawa et al. (2005). In the cases of Minami-Ensei field's samples, the media and the cultivation conditions for quantitative cultivation analysis were conducted in the same manner as described in Nunoura and Takai (2009). The microorganism present in the most diluted series of each medium at each temperature was isolated by the subsequent extinction-dilution method (Takai et al. 2000). The partial sequences of the $16 \mathrm{~S}$ rRNA genes (approx. 700-1,000 bp) of the isolates were determined as described elsewhere (Takai et al. 2004). Although the purity of the isolates was not substantial in this study, it was checked by the cellular morphology on the microscopic observation and the 16S rRNA gene partial sequence. In addition, as it has been often pointed out, the elaborate quantitative cultivations even using numerous media under various growth conditions do not escape from the strong experimental biases and still fail to estimate considerable amounts of various important populations for the microbial communities.

\subsection{Results}

\subsubsection{Fluid Chemistry}

The physical properties and the chemical compositions of the endmember hydrothermal fluids being expelled from the TBS chimney at the Izena Hole Jade field, the 214 chimney at the Izena Hole Hakurei field, and the Jizo and No. 7 chimneys at the Minami-Ensei (Minami-Ensei Knoll) field are summarized in Table 32.1 together with the physicalchemical characteristics of the other endmember hydrothermal fluids in the Okinawa Trough. All of the data in Table 32.1 were already reported in the previous studies (Ishibashi et al. 2014; Kawagucci Chap. 30; Kawagucci et al. 2011, 2013; Konno et al. 2006; Nakagawa et al. 2005; Suzuki et al. 2008; Takai and Nakamura 2010).
As a whole, the high-temperature hydrothermal fluids in the Okinawa Trough deep-sea hydrothermal systems including the Izena Hole Jade and Hakurei fields and the MinamiEnsei field have unique common chemical features represented by the relatively neutral $\mathrm{pH}$ and high concentrations of $\mathrm{K}, \mathrm{NH}_{3}, \mathrm{CO}_{2}$ and $\mathrm{CH}_{4}$, which are tightly associated with the geological settings of Okinawa Trough (Kawagucci, Chap. 30). In the Iheya North and Yonaguni Knoll IV fields, many high-temperature hydrothermal fluids in different chimney sites are affected by the subseafloor phase-separation and -partition processes, and thus, the abundance of gas components in the endmember hydrothermal fluids is highly variable. In contrast, it has been demonstrated that the endmember hydrothermal fluids in the Izena Hole Jade and Hakurei fields and the MinamiEnsei field are little affected by the subseafloor phaseseparation and -partition processes (Ishibashi et al. 2014; Kawagucci et al. 2013).

Notably, the most recent geochemical analysis of various hydrothermal fluids obtained from the Izena Hole Jade and Hakurei fields has led the following interpretation of the hydrothermal activities (Ishibashi et al. 2014): the endmember hydrothermal fluids of both the Jade and Hakurei fields would have the same primary fluid source derived from the common, deep subseafloor hydrothermal reaction zone, while the two major branched fluid paths in the course of the upwelling source fluid flow would generate the two geographically distant, geochemically slightly deviated hydrothermal systems (Jade and Hakurei fields) at the seafloor of the Izena Hole area. The most deviated chemical properties between the endmember hydrothermal fluids of Jade and Hakurei fields are dissolved $\mathrm{H}_{2}$ and $\mathrm{C}_{2} \mathrm{H}_{6}$ concentrations (Table 32.1), which are induced by the presence and the absence of the hydrothermal fluid reaction with sediments (in other words, the thermal decomposition of sedimentary organic compounds) in the subseafloor upwelling hydrothermal fluid flow zones (the presence of sediments in the Hakurei field and the absence of sediments in the Jade field) (Ishibashi et al. 2014). Thus, the different physical and chemical characteristics of hydrothermal fluids and even the different microbial community development patterns would be interpreted as a sort of intra-field variation.

In contrast, although no apparent difference in the $\mathrm{Cl}$ concentration is observed in the high-temperature hydrothermal fluids, the abundance of gas components is found to be slightly variable among the different hydrothermal vent sites of the Minami-Ensei field (Kawagucci et al. 2013). Since the seafloor observation by ROV clearly verified boiling of hydrothermal fluid in several vent sites of the Minami-Ensei field, it seems likely that the phase-separation occurs in the relatively shallow deep-sea hydrothermal system of MinamiEnsei field with a water depth range of 710-730 m. Probably, the boiling of hydrothermal fluid occurs at the seafloor or at 
around the very shallow subseafloor zones. The quite local phase-separation and -partition would provide a little variability in the hydrothermal fluid chemistry at different vent sites of the Minami-Ensei field.

\subsubsection{Biomass in the Hydrothermal Chimney Habitats}

The prokaryotic cell density determined by direct counting of each chimney subsample is listed in Table 32.2. The direct counts of the Minami-Ensei Jizo and No. 7 chimneys were quite difficult due to the very low cell densities recovered from the subsamples and were estimated to be below estimation limit of $10^{4}$ cells/g wet weight (Table 32.2). The quite low cell densities of the Minami-Ensei Jizo and No. 7 chimneys were also expected from the negative results of PCR amplification of bacterial and archaeal 16S rRNA genes: none of the bacterial and archaeal 16S rRNA gene fragments was recovered from the DNA extracts of the subsamples in these chimney structures. In addition, the quantitative PCR analysis using different PCR primer sets showed that the amounts of whole microbial and archaeal $16 \mathrm{~S}$ rRNA genes in these chimney habitats were also below detection limits $(<0.1 \mathrm{fg} / \mathrm{g})$.

In contrast, the directly counted cell densities of the chimney habitats in the Izena Hole Jade and Hakurei fields were comparable with the microbial cell populations previously found in typical chimney habitats of other Okinawa Trough hydrothermal systems (Nakagawa et al. 2005; Nunoura and Takai 2009). In the chimney surface habitats, microbial cell populations with more than $10^{7}$ cells $/ g$ wet weight were detected, and slightly lower or similar cell densities were obtained even from the interior parts of the chimney structures (Table 32.2). In addition, microbial cell population with more than $10^{7}$ cells/g wet weight was estimated in the ISCS deployed in the 214 chimney hydrothermal fluid of the Izena Hole Hakurei field for 5 days (Table 32.2). The recovery of relatively high density of microbial population in the ISCS deployed in the 214 chimney high-temperature hydrothermal fluid is comparable with those in the ISCSs deployed in various vent sites of Iheya North field (Nakagawa et al. 2005) and in the Kali vent site of Kairei field (Takai et al. 2004), but is different from the pattern in the case of ISCS at the Mariner field (Lau Basin) (Takai et al. 2008). Since the ISCS collects the microbial populations entrained by the hydrothermal fluid flow from the subseafloor microbial communities and the microbial population abundance trapped in the ISCS could be relevant with the microbial population abundance entrained by the hydrothermal fluid, the recovery of relatively high density of microbial population in the ISCS at the 214 chimney site may represent the potential population abundance and spatially widespread distribution of subseafloor microbial communities beneath the Izena Hole Hakurei field.

Although microbial cell populations with more than $10^{7}$ cells/g wet weight were detected in the surface habitats of both the TBS and 214 chimneys, the quantitative PCR analysis provided $4.2 \times 10^{5}$ copies/g wet weight and $1.5 \times 10^{5}$ copies/g wet weight for whole prokaryotic $16 \mathrm{~S}$ rRNA gene numbers at the TBS and 214 chimney surface habitats, respectively. In the chimney interior parts, although relatively higher microbial cell densities were obtained from the microscopic observation, only $5.2 \times 10^{3}$ and $5.6 \times 10^{3}$ copies/g wet weight for whole prokaryotic $16 \mathrm{~S}$ rRNA gene numbers were obtained from the TBS and 214 chimneys, and $1.4 \times 10^{3}$ copies/g wet weight for total $16 \mathrm{~S}$ rRNA gene number was found in the ISCS deployed at the 214 chimney. The proportion of archaeal 16S rRNA gene number against the bacterial counterpart was quite low among all the chimney habitats (Table 32.2), which are comparable with any of the previously known values of the chimney habitats in various deep-sea hydrothermal systems.

\subsubsection{Bacterial and Archaeal Phylotypes in the Chimney Habitats}

The archaeal and bacterial 16S rRNA gene phylotype compositions of the chimney habitats are shown in Tables 32.3 and 32.4. The phylogenetic affiliation of the phylotype is characterized by the phylogenetic analysis of representative phylotype sequences. The archaeal 16S rRNA genes were only successfully amplified from the samples of the 214 chimney and ISCS at the Hakurei field (Table 32.3). The predominant archaeal 16S rRNA gene phylotypes from the 214 chimney surface habitat were all closely related with the previously known (hyper)thermophilic archaeal genera such as Methanothermococcus, Methanocaldococcus, Methanopyrus, Thermococcus and Pyrodictium (Table 32.3). In the ISCS deployed at the high-temperature hydrothermal fluid for 5 days, only one phylotype of Methanothermococcus dominated the archaeal 16S rRNA phylotype composition and three representative phylotypes related with Nanoarchaeota occupied the archaeal 16S rRNA phylotype composition in the interior part of the 214 chimney (Table 32.3). These archaeal 16S rRNA gene phylotypes are closely related with the (hyper)thermophilic archaeal populations that have been frequently identified in the global deep-sea hydrothermal vent environments although these archaeal 16S rRNA gene phylotypes represent quite low fractions of whole prokaryotic 16S rRNA gene assemblages (Table 32.2).

The bacterial 16S rRNA gene phylotypes were obtained from the TBS chimney and the 214 chimney and its ISCS of the Jade and Hakurei fields (Table 32.4). However, the 


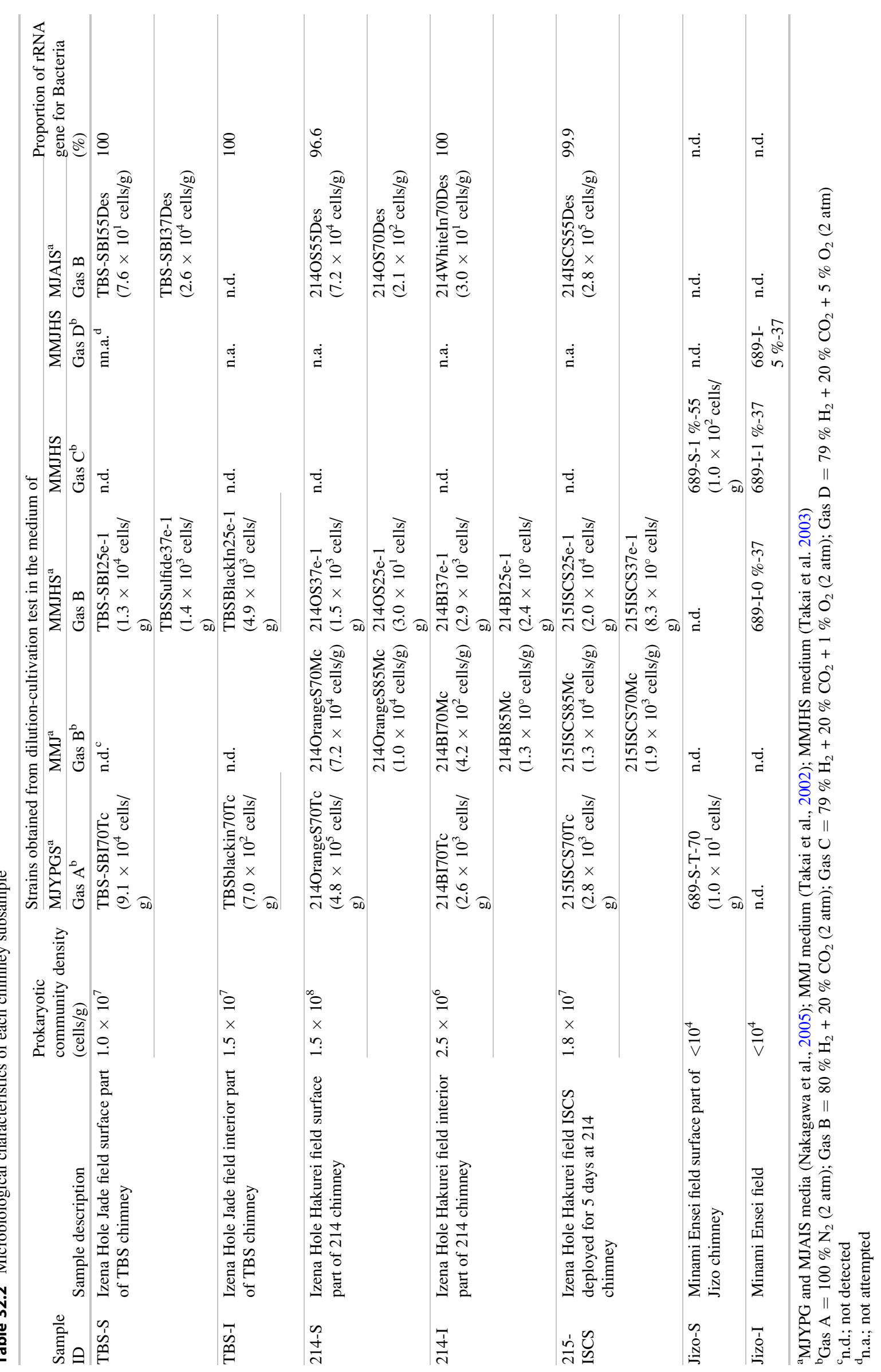


Table 32.3 Distribution of representative archaeal 16S rRNA gene phylotypes in the various chimney subsamples

\begin{tabular}{llll}
\hline & \multicolumn{3}{l}{ Number of clones from } \\
\cline { 2 - 4 } Phylogenetic affiliation & $214-\mathrm{S}$ & $214-\mathrm{I}$ & $215-$ ISCS \\
\hline Nanoarchaeota & - & 29 & - \\
\hline Crenarchaeota & & & - \\
\hline \multicolumn{1}{c}{ Desulfurococcales } & 1 & - & - \\
\hline Euryarchaeota & & & - \\
\hline$\quad$ Methanopyrales & 2 & - & 45 \\
\hline$\quad$ Methanococcales & 22 & - & - \\
\hline$\quad$ Thermococcales & 19 & - & 45 \\
\hline Total & 44 & 29 & \\
\hline
\end{tabular}

Table 32.4 Distribution of representative bacterial 16S rRNA gene phylotypes in the various chimney subsamples

\begin{tabular}{|c|c|c|c|c|c|}
\hline \multirow[b]{2}{*}{ Phylogenetic affiliation } & \multicolumn{5}{|c|}{ Number of clones from } \\
\hline & $\begin{array}{l}\text { TBS- } \\
\text { S }\end{array}$ & $\begin{array}{l}\text { TBS- } \\
\text { I }\end{array}$ & $\begin{array}{l}214- \\
S\end{array}$ & $\begin{array}{l}214- \\
\text { I }\end{array}$ & $\begin{array}{l}215- \\
\text { ISCS }\end{array}$ \\
\hline \multicolumn{6}{|l|}{ Aquificae } \\
\hline Aquifex group & - & - & 1 & - & - \\
\hline Desulfurobacteria group & - & - & 4 & - & - \\
\hline CFB Group & - & - & - & - & 3 \\
\hline Chloroflexi & 16 & 1 & - & - & - \\
\hline Planctmycetes & 8 & - & - & 1 & \\
\hline Actinobacteria & 15 & 2 & - & 13 & 3 \\
\hline Firmicutes & - & 1 & - & 1 & 4 \\
\hline \multicolumn{6}{|l|}{ Proteobacteria } \\
\hline Alphaproteobacteria & - & 1 & - & 7 & 3 \\
\hline Betaproteobacteria & - & 3 & - & 8 & 12 \\
\hline \multicolumn{6}{|l|}{ Gammaproteobacteria } \\
\hline Thiomicrospira group & 1 & - & - & - & - \\
\hline Deltaproteobacteria & 1 & - & - & - & - \\
\hline \multicolumn{6}{|l|}{ Epsilonproteobacteria } \\
\hline Nautiliaceae & - & - & 14 & - & - \\
\hline $\begin{array}{l}\text { Campylobacteraceae, } \\
\text { Sulfurospirillum group }\end{array}$ & - & - & 1 & - & - \\
\hline $\begin{array}{l}\text { Thiovulgaceae, Sulfurovum } \\
\text { group }\end{array}$ & 1 & - & 5 & - & - \\
\hline Nitratiruptor group & - & - & 12 & - & - \\
\hline Thioreductor group & - & - & 4 & - & - \\
\hline Total & 42 & 8 & 35 & 30 & 25 \\
\hline
\end{tabular}

bacterial 16S rRNA gene phylotype compositions in the TBS chimney interior habitat, the 214 chimney interior habitat and the 214 ISCS were not likely derived from the indigenous microbial communities in the in situ habitats (Table 32.4). Most of the predominant bacterial phylotypes from these samples were closely related with previously cultured and uncultured members of Actinobacteria, Alphaproteobacteria and Betaproteobacteria obtained from non-hydrothermal environments and not from marine environments. Considering the quite low numbers of whole prokaryotic $16 \mathrm{~S}$ rRNA genes recovered by the quantitative
PCR, it seems very likely that these bacterial $16 \mathrm{~S}$ rRNA gene phylotypes do not represent the predominant bacterial components in the indigenous microbial communities associated with the high-temperature hydrothermal fluid flows. Rather, these bacterial 16S rRNA gene phylotypes may be derived from the contaminants from other environments such as seawater and onboard and onshore laboratory environments. In contrast, the bacterial $16 \mathrm{~S}$ rRNA gene phylotype compositions in the TBS chimney and the 214 chimney surface habitats seemed to represent the predominant bacterial components in the indigenous microbial communities (Table 32.4). All the bacterial 16S rRNA gene phylotypes obtained from the 214 chimney surface were closely related with the members of Aquificae and Epsilonproteobacteria, predominant microbial populations in many of the deep-sea hydrothermal environments. Similarly, the bacterial 16S rRNA gene phylotype composition in the TBS chimney surface hosted the bacterial phylotypes related with the deep-sea vent epsilon-, delta- and gammaproteobacterial components although the clonal abundances of these phylotypes were low (Table 32.4). Other than these typical deep-sea vent proteobacterial components, in the TBS chimney surface habitats, the bacterial phylotypes within the Chloroflexi, Planctomycetes and Actinobacteria dominated the clone library (Table 32.4). Most of these Chloroflexi, Planctomycetes and Actinobacteria phylotypes were phylogenetically related with the bacterial phylotypes detected in the inactive chimneys or the active but highly weathered chimney outer surface parts of the Okinawa Trough, Indian Ocean and Lau Basin (Suzuki et al. 2004; Takai et al. 2008). Thus, the bacterial 16S rRNA gene phylotype composition in the TBS chimney surface is likely derived from the indigenous microbial community in the in situ surface habitat of the TBS chimney of the Jade field.

\subsubsection{Cultivation Analyses of Microbial Components}

We attempted to estimate the viable counts of potentially predominant microbial components living in the chimney environments by means of a liquid serial dilution cultivation technique. The viable count of each strain and the estimated population size of each taxonomic group are shown in Table 32.2 and Fig. 32.1, respectively.

As a whole, very diverse cultivated microbial populations were obtained from four chimney habitats of the Izena Hole and Minami-Ensei hydrothermal fields and the great variability in the abundance and diversity of cultivated microbial community was evident between the chimney sites (Fig. 32.1). The most diverse cultivated microbial populations were found in the 214 chimney of the Izena Hole Hakurei field. Nine different genera of mesophilic to 

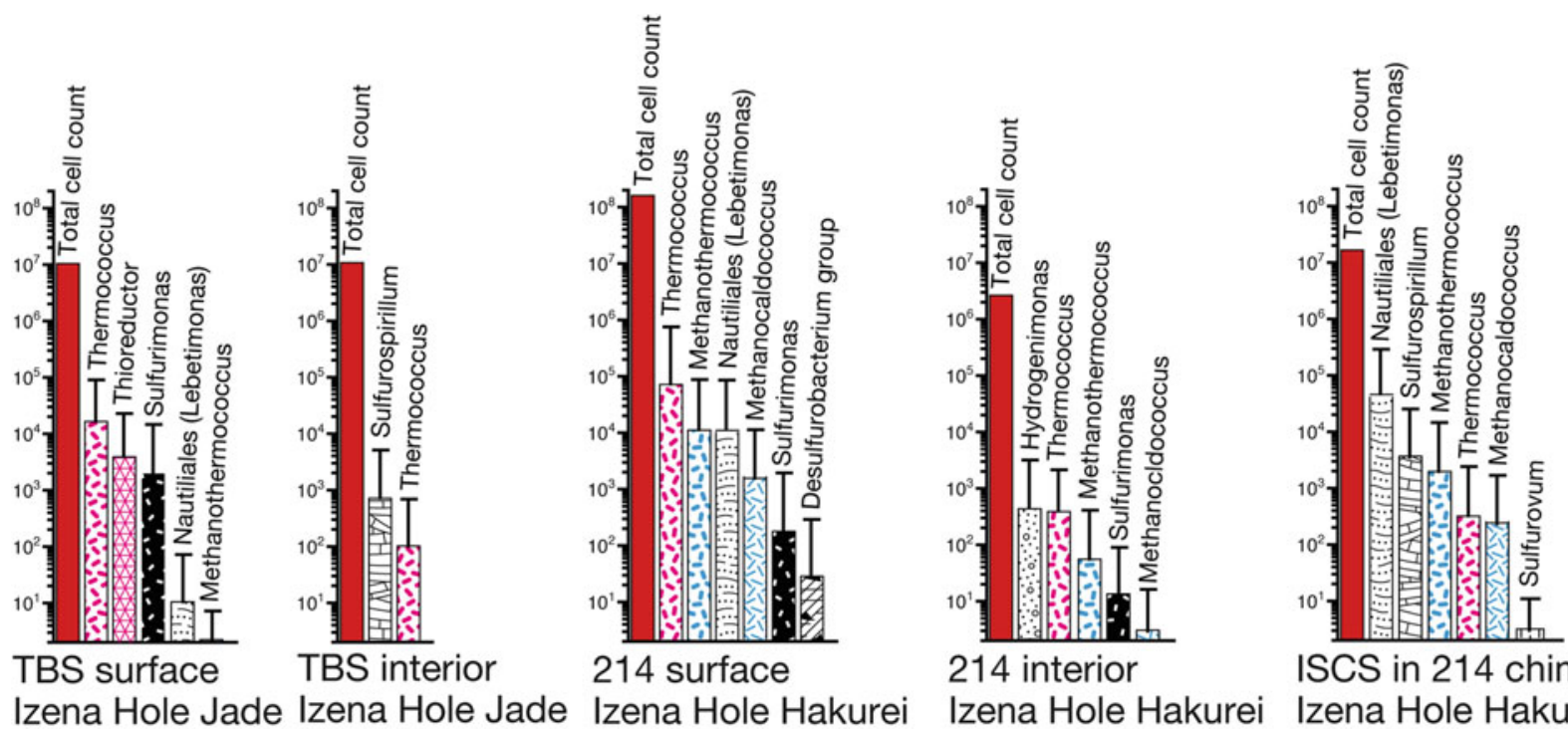

ISCS in 214 chimney site Izena Hole Hakurei
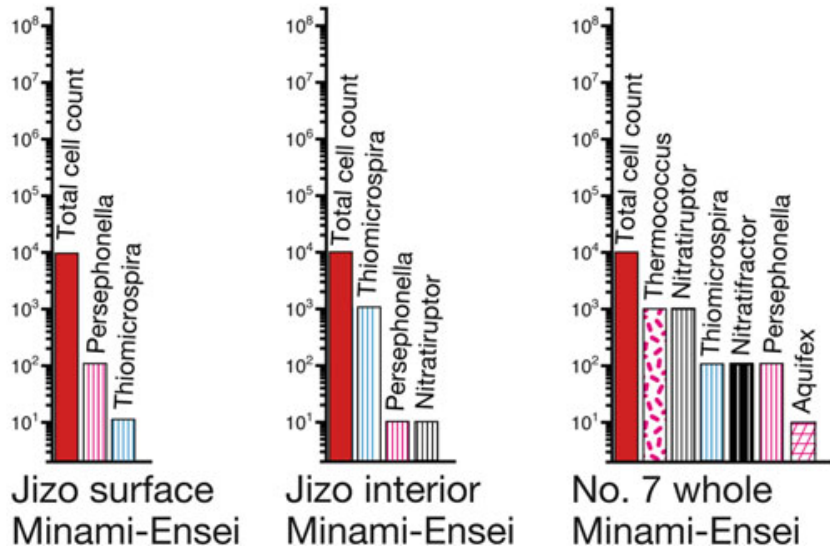

Fig. 32.1 Total cell count and viable count determined using DAPI staining and serial dilution cultivation in chimney habitats. The phylogenetic affiliation of isolates was delineated from the phylogenetic tree analysis. The abundances of cultivated microbial populations in the

hyperthermophilic deep-sea vent-endemic microbial populations were cultivated from the chimney habitats (Fig. 32.1). It was interesting that most of the cultivated components were common in between the TBS and 214 chimney sites of Izena Hole Jade and Hakurei fields or in between the Jizo and No. 7 chimneys of the Minami-Ensei field, while the cultivated components were significantly distinct in between the Izena Hole fields and the MinamiEnsei field (Fig. 32.1).

In the Izena Hole fields, the predominant cultivated microbial populations were Thermococcus, Nautiliales, Hydrogenimonas, Thioreductor, Sulfurimonas and Sulfurospirillum members (Fig. 32.1). Among these members, the predominant occurrence of cultivated Hydrogenimonas, Thioreductor and Sulfurospirillum populations was atypical in the deep-sea hydrothermal environments other than the

Izena Hole Jade and Hakurei chimneys are shown with the minimum estimation (column) and the maximum estimation (bar). The abundances of cultivated microbial populations in the Minami-Ensei chimneys are shown only with the maximum estimation (column)

Okinawa Trough, and the predominant cultivation of Sulfurospirillum population was unique in the Izena Hole hydrothermal fields, although the considerable population of Sulfurospirillum members has been cultivated from the chimney habitats and the polychaetes colonies of the Iheya North and Yonaguni Knoll IV fields using a specific mixotrophic media enriched with formate (unpublished data). The Sulfurospirillum members are known to be psychrophilic to slightly thermophilic chemolithomixotrophs and to require formate and simple organic acids in addition $\mathrm{H}_{2}$ as the primary energy sources (Campbell et al. 2006). The first detection of Sulfurospirillum members as one of the predominant cultivated microbial populations in the Izena Hole fields, particularly in the Hakurei field, may be associated with the hydrothermal fluid chemistry, e.g., relative enrichment of formate in the hydrothermal fluids as 
observed in the thermogenic hydrocarbons compared to other deep-sea hydrothermal fluids in the Okinawa Trough and the MOR, systems. However, the significant difference was found in the comparison of cultivated microbial community structures between the two Izena Hole fields, which should be an intra-field variability as described above. The cultivated population abundances of (hyper)thermophilic hydrogenotrophic methanogens such as Methanothermococcus and Methanocaldococcus were significant in the Hakurei field but were quite little in the Jade field (Fig. 32.1). This was the most outstanding intra-field difference of the cultivated microbial community structures in the Izena Hole hydrothermal system.

In the Minami-Ensei field, the cultivated microbial communities consisted of members of Thermococcus, Aquifex, Persephonella, Nitratiruptor, Nitratifractor and Thiomicrospira (Fig. 32.1). Among these members, the Thermococcus, Aquifex and Persephonella populations have been very often detected as predominant cultivated populations in many of the deep-sea hydrothermal environments including the Okinawa Trough systems (Takai and Nakamura 2010, 2011), and the Nitratiruptor and Nitratifractor members also represent typical cultivated populations in the Iheya North chimney habitats (Nakagawa et al. 2005). However, the predominant occurrence of cultivated Thiomicrospira population has been observed only in the $\mathrm{S}^{0}$ chimney of the TOTO caldera field, the Mariana Volcanic Arc (Nakagawa et al. 2006), and may be a unique feature of the microbial communities in the chimney habitats of the Minami Ensei field (Fig. 32.1).

\subsection{Discussion}

\subsubsection{Intra-Field Variability in Hydrothermal Fluid Chemistry and Microbial Community Development}

In two hydrothermal fields of the Izena Hole area, the physical and chemical characteristics of the endmember hydrothermal fluids are quite similar other than the dissolved $\mathrm{H}_{2}$ and $\mathrm{C}_{2} \mathrm{H}_{6}$ concentrations, probably due to the occurrence of the common, deep subseafloor hydrothermal reaction zones (Table 32.1) (Ishibashi et al. 2014). However, it is very likely that the dissolved $\mathrm{H}_{2}$ concentration has a great impact on the microbial community development in the chimney habitats associated with the high-temperature hydrothermal fluids. The significant variability in the cultivated population abundances of (hyper)thermophilic hydrogenotrophic methanogens such as Methanothermococcus and Methanocaldococcus in the chimney habitats is evident (Fig. 32.1). The predominant occurrence of these (hyper) thermophilic hydrogenotrophic methanogens' populations in the microbial communities of the chimney habitats is also in part supported by the cultivation-independent $16 \mathrm{~S}$ rRNA gene clone analyses, in which their 16S rRNA gene sequences are recovered only from the 214 chimney and the ISCS habitats in the Izena Hole hydrothermal system (Table 32.3), although the $16 \mathrm{~S}$ rRNA gene clone analyses do not very much provide the quantitative insight into the microbial phylotype compositions. It is empirically justified and statistically supported by the geochemical analysis of dissolved $\mathrm{H}_{2}$ concentration in the proximal hydrothermal fluids and the quantitative estimation of cultivated (hyper) thermophilic hydrogenotrophic methanogens' populations (Takai and Nakamura 2010, 2011). Not only the increased cultivated population abundances of (hyper)thermophilic hydrogenotrophic methanogens but also the greater diversity of cultivated microbial populations in the Izena Hole hydrothermal system are likely affected by the enrichment of dissolved $\mathrm{H}_{2}$ in the adjacent hydrothermal fluids (Fig. 32.1). This can be theoretically justified by the thermodynamic estimation of potential energy yields of various chemolithotrophic energy metabolisms in the hydrothermal mixing zones of habitats (Nakamura and Takai 2014; Takai and Nakamura 2010, 2011; Nakamura and Takai Chap. 2). Most of potential energy yields of thiotrophic chemolithotrophic metabolisms in the hydrothermal mixing zones are constrained by the dissolved $\mathrm{O}_{2}$ concentration in the ambient seawater while those of hydrogenotrophic metabolisms are proportionated by the dissolved $\mathrm{H}_{2}$ concentration in the hydrothermal fluid due to much greater abundances and availability of electron acceptors such as $\mathrm{CO}_{2}$ and sulfate other than $\mathrm{O}_{2}$ in the mixing zones (Nakamura and Takai 2014, Chap. 2). Thus, it is predicted that the intra-field variability in the hydrothermal fluid $\mathrm{H}_{2}$ concentration much more significantly affects the microbial community development in the chimney habitat than the intra-field variability in concentrations of other hydrothermal fluid gas components.

Similarly, the intra-field variability in the microbial community development is perceived in the chimney habitats of the Minami-Ensei field (Fig. 32.1). The abundance and diversity of cultivated microbial communities (e.g., Thermococcus, Nitratiruptor, Nitratifractor, Persephonella and Aquifex populations) were greater in the No. 7 chimney than in the Jizo chimney (Fig. 32.1). In the Minami-Ensei field, it has been suggested that the hydrothermal fluid chemistry of endmember hydrothermal fluid is little affected by the subseafloor phase-separation and -partition processes (Kawagucci et al. 2013). However, there is found the slight deviation of dissolved gas concentrations in the hydrothermal fluids at different chimney sites probably due to the phase-separation and -partition near the seafloor (Table 32.1) (Kawagucci et al. 2013). Indeed, the dissolved $\mathrm{H}_{2}, \mathrm{H}_{2} \mathrm{~S}$ and $\mathrm{CH}_{4}$ concentrations in the hydrothermal fluid are slightly 
higher at the No. 7 chimney site than at the Jizo chimney site (Table 32.1). The cultivated microbial populations that represent the intra-field variation of abundance and incidence are known to be capable of growth with hydrogenotrophic and thiotrophic chemolithoautotrophy except for Thermococcus (Fig. 32.1). The intra-field variability in the active microbial community significantly associated with phase-separation-induced chemical variation has been demonstrated in the case studies of the Iheya North (Iheya North Knoll) field (Nakagawa et al. 2005) and the Yonaguni Knoll IV (Daiyon-Yonaguni Knoll) field (Nunoura and Takai 2009). Thus, as observed in the Iheya North (Nakagawa et al. 2005) and the Yonaguni Knoll IV fields (Nunoura and Takai 2009), despite the slight differences, the intra-field variation in the hydrothermal fluid gas chemistry may lead to the intra-field variability in the microbial community development in the Minami-Ensei field.

\subsubsection{Inter-Fields Variability in Microbial Community Development in the Okinawa Trough}

This study shows variability in the microbial communities in the microbial habitats associated with the endmember-like high-temperature hydrothermal fluids in the Izena Hole and Minami-Ensei hydrothermal fields of the Okinawa Trough. Combining the physical and chemical characteristics of hydrothermal fluids determined in the previous studies (Ishibashi et al. 2014; Kawagucci et al. 2013) and the microbial community patterns delineated from this study with the accumulated information in other deep-sea hydrothermal systems of the Okinawa Trough (Tables 32.1 and 32.5), the inter-fields variability in microbial community development is discussed here.

As compared to the cultivated microbial community patterns in the Iheya North and Yonaguni Knoll IV chimney habitats, the abundance and diversity of cultivated microbial community in the Izena Hole Hakurei chimney are comparable with those in the chimney habitats hosting the gasenriched hydrothermal fluids in the Iheya North and Yonaguni Knoll IV fields (Tables 32.1 and 32.5). These chimney habitats that represent the greater abundance and diversity of cultivated microbial community are characterized by relatively high concentrations of $\mathrm{H}_{2}$ in the adjacent hydrothermal fluids $\left(0.23\right.$ to $\left.2.4 \mathrm{mM} \mathrm{H} \mathrm{H}_{2}\right)$ (Table 32.1). In contrast, the cultivated microbial communities in the Minami-Ensei chimney habitats are less abundant and diverse as compared to the cultivated microbial communities in the chimney habitats of other Okinawa Trough deep-sea hydrothermal systems (Table 32.5) and even other global deep-sea hydrothermal systems such as the TOTO Caldera field in the Mariana
Volcanic Arc (Nakagawa et al. 2006), the Mariner field in the Lau Basin (Takai et al. 2008) and the Brother Caldera field in the Kermadec Arc (Takai et al. 2009). The less abundant and diverse cultivated microbial communities in the Minami-Ensei field may be caused by the much lower concentration of $\mathrm{H}_{2} \mathrm{~S}$ in the hydrothermal fluids $(<1 \mathrm{mM})$ as compared to other deep-sea hydrothermal systems. However, the relatively low concentrations of hydrothermal fluid $\mathrm{H}_{2} \mathrm{~S}$ have been known in the Middle Valley field of the Juan de Fuca Ridge (1.1-1.5 mM) (Von Damm 1995), Rainbow field (1.2 mM) and Logatchev field (0.5-0.8 mM) (Charlou et al. 2002), whereas the occurrences of quite diverse and highly active microbial communities in these deep-sea hydrothermal environments have been strongly pointed by the multidisciplinary biogeochemical and microbiological characterizations (Flores et al. 2011; Frank et al. 2013; Perner et al. 2007, 2013). Rather than the hydrothermal fluid chemistry, the physical properties of the chimney structures and the physical behavior of hydrothermal fluid flow in the chimneys may more significantly affect the indigenous microbial community development. In the Minami-Ensei field, all the chimney structures were very fragile and porous, and the high-temperature hydrothermal fluid discharges were found not from the focused orifices of the chimneys but from whole surface areas of the chimneys. In such chimney structures, it is expected that the hydrothermal mixing is very fluctuated and the microbiologically habitable zones are temporally and spatially unstable due to the frequent exposure to high-temperature hydrothermal fluid flows that would be lethal to the development of indigenous microbial community or the frequent collapse of chimney structures. Indeed, only the quite low abundances of microbial cell density and 16S rRNA gene number were obtained from the chimney structures in the Minami-Ensei field (Table 32.2). The reproduction rate and pattern of microbial communities in the newly created chimney habitats would be influenced by the abundance and diversity of seed microbial populations mainly entrained by the hydrothermal fluids from the ambient hydrothermal mixing fluids and the potential subseafloor microbial communities. Thus, the microbial community development in the deep-sea hydrothermal vent chimneys may be relevant with the age of hydrothermal system and the hydrogeological complexity of subseafloor hydrothermal fluid flow structures that would sustain the potential resilience of chimney and other seafloor microbial communities in the deep-sea hydrothermal systems.

The previous investigations have demonstrated the statistically supported correlation between the dissolved $\mathrm{H}_{2}$ concentration in hydrothermal fluid and the total culturable population abundance of (hyper)thermophilic hydrogenotrophic methanogens (Takai and Nakamura 2010, 2011). In the analysis including new data obtained in 


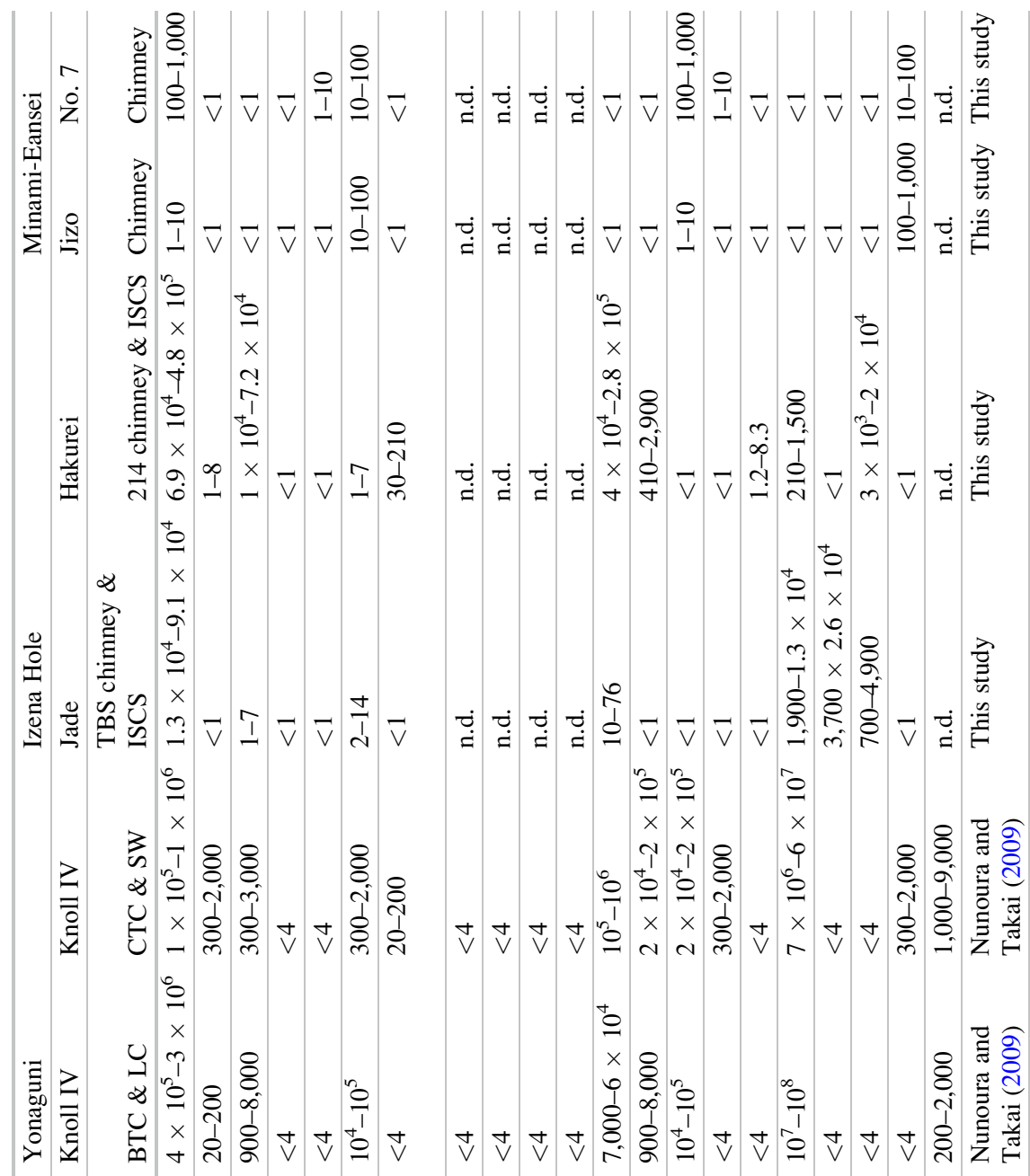

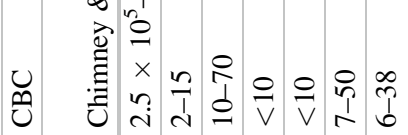

\section{:}

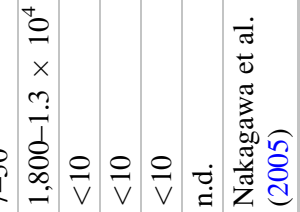

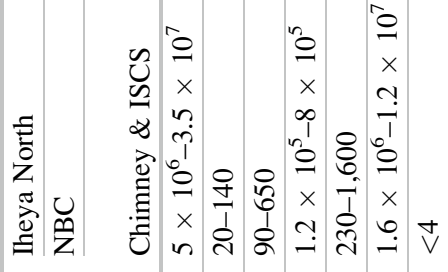

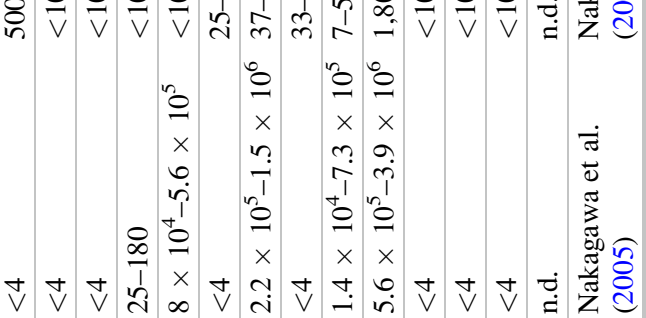

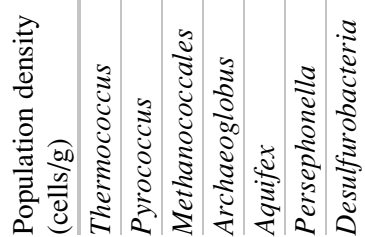

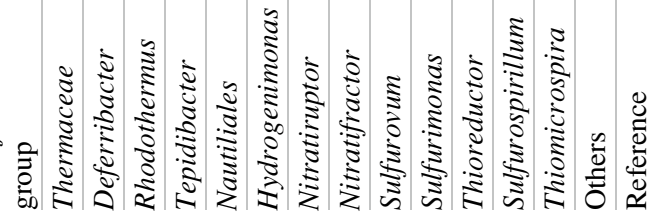




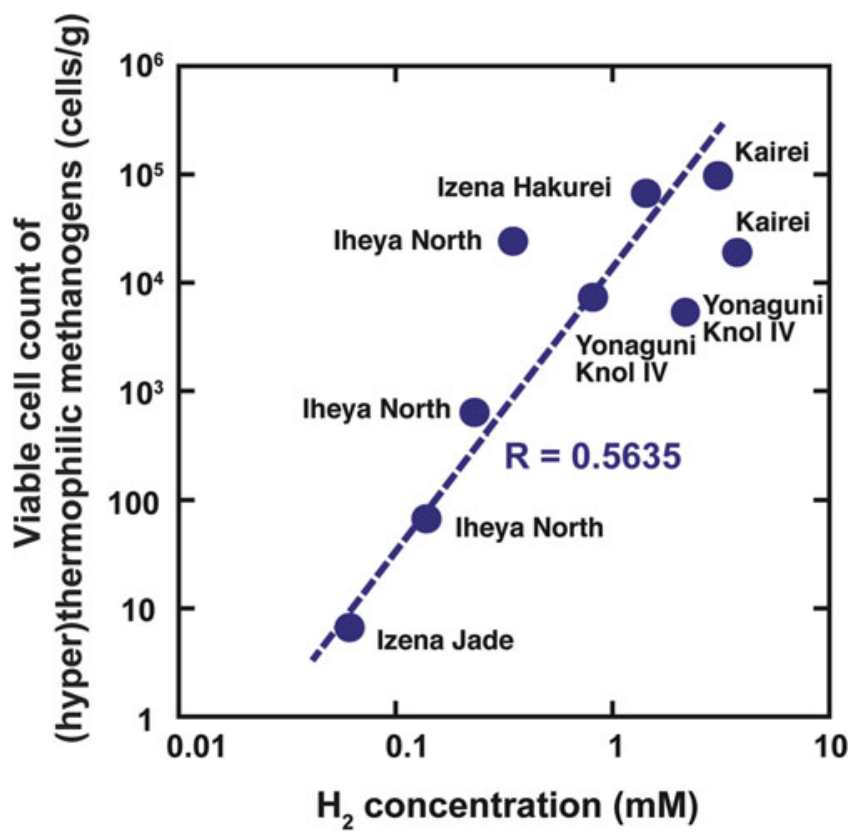

Fig. 32.2 Correlation between cultivated population of the (hyper) thermophilic hydrogenotrophic methanogens and dissolved $\mathrm{H}_{2}$ concentration in adjacent endmember hydrothermal fluid. Moderate correlation is found between them (dot line)

this study (Fig. 32.2), the correlation is statistically validated with a higher regression constant than in the previous studies (Fig. 32.2) (Takai and Nakamura 2010, 2011). The correlation between the dissolved $\mathrm{H}_{2}$ concentration in hydrothermal fluid and the culturable population abundance of (hyper) thermophilic hydrogenotrophic methanogens can be predicted by the thermodynamic estimation of potential energy yields of various chemolithotrophic energy metabolisms in the hydrothermal mixing zones of habitats (Nakamura and Takai 2014, Chap. 2). The potential energy available for hydrogenotrophic methanogenesis in the hydrothermal mixing zones is primarily dependent on the $\mathrm{H}_{2}$ input from the hydrothermal fluids since the electron acceptor and carbon source $\left(\mathrm{CO}_{2}\right)$ can be supplied both from the hydrothermal fluids and ambient seawater and be more abundant in the hydrothermal mixing zones than $\mathrm{H}_{2}$ (Nakamura and Takai 2014, Chap. 2). Only if the dissolved $\mathrm{O}_{2}$, which is lethal to most of the methanogens, is fully removed from the microbial habitats in hydrothermal mixing zones, the productivity of hydrogenotrophic methanogens would be primarily controlled by $\mathrm{H}_{2}$ concentration in the adjacent hydrothermal fluids. Although greater number of deep-sea vent examples and data will be essential for future study to justify the linkages between microbial community development and chemical characteristics in deep-sea hydrothermal ecosystems, it seems very likely that the $\mathrm{H}_{2}$ concentration in the hydrothermal fluid is the only chemical factor directly to control the thermodynamic energy potential and the existent biomass and production of the (hyper) thermophilic hydrogenotrophic methanogens in the global deep-sea hydrothermal environments.

Acknowledgments We are grateful to the captain and crews of the research vessel Natsushima and the operation teams of the manned submersible Shinkai 2000 and the remotely operative vehicle Hyperdolphin for their technical expertise and safety at sea. We wish to thank onboard scientists of the cruises for their support. This work was supported in part by Grand-in-Aid for Science Research of TAIGA project (No. 20109005) from MEXT, Japan.

Open Access This chapter is distributed under the terms of the Creative Commons Attribution Noncommercial License, which permits any noncommercial use, distribution, and reproduction in any medium, provided the original author(s) and source are credited.

\section{References}

Campbell BJ, Engel AS, Porter ML, Takai K (2006) The versatile epsilon-proteobacteria: key players in sulphidic habitats. Nat Rev Microbiol 4:458-468

Charlou JL, Donval JP, Fouquet Y, Jean-Baptiste P, Holm N (2002) Geochemistry of high $\mathrm{H}_{2}$ and $\mathrm{CH}_{4}$ vent fluids issuing from ultramafic rocks at the rainbow hydrothermal field $\left(36^{\circ} 14^{\prime}\right.$, MAR). Chem Geol 191:345-359

DeLong EF (1992) Archaea in coastal marine environments. Proc Natl Acad Sci U S A 89:5685-5689

Flores GE, Campbell JH, Kirshtein JD, Meneghin J, Podar M, Steinberg JI, Seewald JS, Tivey MK, Voytek MA, Yang ZK, Reysenbach A-L (2011) Microbial community structure of hydrothermal deposits from geochemically different vent fields along the Mid-Atlantic Ridge. Environ Microbiol 13:2158-2171

Frank KL, Rogers DR, Olins HC, Vidoudez C, Girguis PR (2013) Characterizing the distribution and rates of microbial sulfate reduction at Middle Valley hydrothermal vents. ISME J 7:1391-1401

Glasby GP, Notsu K (2003) Submarine hydrothermal mineralization in the Okinawa Trough, SW of Japan: an overview. Ore Geol Rev 23:299-339

Huber JA, Holden JF (2008) Modeling the impact of diffuse vent microorganisms along Mid-Ocean Ridges and Flanks. In: Magma to microbe: modeling hydrothermal processes at oceanic spreading centers, Geophysics Monograph. AGU, Washington, DC, pp 215-231

Hugenholtz P (2002) Exploring prokaryotic diversity in the genomic era. Genome Biol 3, reviews0003.1-0003.8

Ishibashi J, Noguchi T, Toki T, Miyabe S, Yamagami S, Ohnishi Y, Yamanaka T, Yokoyama Y, Omori R, Takahashi Y, Hatada K, Nakaguchi J, Yoshizaki M, Konno U, Shibuya T, Takai K, Inagaki F, Kawagucci S (2014) Similarity and diversity of fluid geochemistry in active hydrothermal fields in the Izena Cauldron, in the middle Okinawa Trough back-arc basin. Geochem J 48:357-369

Kawagucci S, Chiba H, Ishibashi J, Yamanaka T, Toki T, Muramatsu Y, Ueno Y, Makabe A, Inoue K, Yoshida N, Nakagawa S, Nunoura T, Takai K, Takahata N, Sano Y, Narita T, Teranishi G, Obata H, Gamo T (2011) Hydrothermal fluid geochemistry at the Iheya North field in the mid-Okinawa Trough: implication for origin of methane in subseafloor fluid circulation systems. Geochem J 45:109-124

Kawagucci S, Ueno Y, Takai K, Toki T, Ito M, Inoue K, Makabe A, Yoshida N, Muramatsu Y, Takahata N, Sano Y, Narita T, Teranishi G, Obata H, Nakagawa S, Nunoura T, Gamo T (2013) Geochemical 
origin of hydrothermal fluid methane in sediment-associated fields and its relevance to the geographical distribution of whole hydrothermal circulation. Chem Geol 339:213-225

Konno U, Tsunogai U, Nakagawa S, Nakaseama M, Ishibashi J, Nunoura T, Nakamura K (2006) Liquid $\mathrm{CO}_{2}$ venting on the seafloor: Yonaguni Knoll IV hydrothermal system, Okinawa Trough. Geophys Res Lett 33, L16607

Lane DJ (1991) 16S/23S sequencing. In: Stackebrandt E, Goodfellow M (eds) Nucleic acid techniques in bacterial systematics. Wiley, New York, pp 115-176

Letouzey J, Kimura M (1986) The Okinawa Trough: genesis of a back-arc basin developing along a continental margin. Tectonophys 125:209-230

Ludwig W, Strunk O, Westram R, Richter L, Yadhukumar HM, Buchner A, Lai T, Steppi S, Jobb G, Förster W, Brettske I, Gerber S, Ginhart AW, Gross O, Grumann S, Hermann S, Jost R, König A, Liss T, Lüßmann R, May M, Nonhoff B, Reichel B, Strehlow R, Stamatakis A, Stuckmann N, Vilbig A, Lenke M, Ludwig T, Bode A, Schleifer KH (2004) ARB: a software environment for sequence data. Nucleic Acids Res 32:1363-1371

McCollom TM (2007) Geochemical constraints on sources of metabolic energy for chemolithoautotrophy in ultramafic-hosted deepsea hydrothermal systems. Astrobiol 7:933-950

McCollom TM, Shock EL (1997) Geochemical constraints on chemolithoautotrophic metabolism by microorganisms in seafloor hydrothermal systems. Geochim Cosmochim Acta 61:4375-4391

Nakagawa S, Takai K (2008) Deep-sea vent chemoautotrophs: diversity, biochemistry and ecological significance. FEMS Microbiol Ecol 65:1-14

Nakagawa S, Takai K, Inagaki F, Chiba H, Ishibashi J, Kataoka S, Hirayama H, Nunoura T, Horikoshi K, Sako Y (2005) Variability in microbial community and venting chemistry in a sediment-hosted backarc hydrothermal system: impacts of subseafloor phaseseparation. FEMS Microbiol Ecol 54:141-155

Nakagawa T, Takai K, Suzuki Y, Hirayama H, Konno U, Tsunogai U, Horikoshi K (2006) Geomicrobiological exploration and characterization of a novel deep-sea hydrothermal system at the TOTO caldera in the Mariana Volcanic Arc. Environ Microbiol $8: 37-49$

Nakamura K, Takai K (2014) Theoretical constraints of physical and chemical properties of hydrothermal fluids on variations in chemolithotrophic microbial communities in seafloor hydrothermal systems. Prog Earth Plant Sci 1:1-24

Nunoura T, Takai K (2009) Comparison of microbial communities associated with phase-separation-induced hydrothermal fluids at the Yonaguni Knoll IV hydrothermal field, the Southern Okinawa Trough. FEMS Microbiol Ecol 67:351-370

Perner M, Kuever J, Seifert R, Pape T, Koschinsky A, Schmidt K, Strauss H, Imhoff JF (2007) The influence of ultramafic rocks on microbial communities at the Logatchev hydrothermal field, located 15 degrees N on the Mid-Atlantic Ridge. FEMS Microbiol Ecol 61:97-109

Perner M, Hansen M, Seifert R, Strauss H, Koschinsky A, Petersen S (2013) Linking geology, fluid chemistry, and microbial activity of basalt- and ultramafic-hosted deep-sea hydrothermal vent environments. Geobiol 11:340-355

Reysenbach A-L, Banta AB, Boone DR, Cary SC, Luther GW (2000) Microbial essentials at hydrothermal vents. Nature 404:835-845

Shock EL, Holland ME (2004) Geochemical energy sources that support the subsurface biosphere. In: Wilcock WSD, Delong EF, Kelley DS, Baross JA, Cary SC (eds) The subseafloor biosphere at mid-ocean ridges, vol 144, Geophysics monograph series. AGU, Washington, DC, pp 153-165
Suzuki Y, Inagaki F, Takai K, Nealson KH, Horikoshi K (2004) Microbial diversity in inactive chimney structures from deep-sea hydrothermal systems. Microbial Ecol 47:186-196

Suzuki R, Ishibashi J, Nakaseama M, Konno U, Tsunogai U, Gena K, Chiba H (2008) Diverse range of mineralization induced by phase separation of hydrothermal fluid: case study of the Yonaguni Knoll IV hydrothermal field in the Okinawa Trough back-arc basin. Res Geol 58:267-288

Takai K, Horikoshi K (2000) Rapid detection and quantification of members of the archaeal community by quantitative PCR using fluorogenic probes. Appl Environ Microbiol 66:5066-5072

Takai K, Nakamura K (2010) Compositional, physiological and metabolic variability in microbial communities associated with geochemically diverse, deep-sea hydrothermal vent fluids. In: Barton LL, Mandl M, Loy A (eds) Geomicrobiology: molecular and environmental perspective. Springer, New York, pp 251-283

Takai K, Nakamura K (2011) Archaeal diversity and community development in deep-sea hydrothermal vents. Curr Opin Microbiol 14:282-291

Takai K, Inoue A, Horikoshi K (1999) Thermaerobacter marianensis gen. nov., sp. nov., an aerobic extremely thermophilic marine bacterium from the 11,000 m deep Mariana Trench. Int J Syst Bacteriol 49:619-628

Takai K, Inoue A, Horikoshi K (2000) Thermosipho japonicus sp. nov., an extremely thermophilic bacterium isolated from a deep-sea hydrothermal vent in Japan. Extremophiles 4:9-17

Takai K, Moser DP, Deflaum M, Onstott TC, Fredrickson JK (2001) Archaeal diversity in waters from deep South African gold mines. Appl Environ Microbiol 67:5750-5760

Takai K, Inoue A, Horikoshi K (2002) Methanothermococcus okinawensis sp. nov., a thermophilic, methane-producing archaeon isolated from a Western Pacific deep-sea hydrothermal vent system. Int J Syst Evol Microbiol 52:1089-1095

Takai K, Inagaki F, Nakagawa S, Hirayama H, Nunoura T, Sako Y, Nealson KH, Horikoshi K (2003) Isolation and phylogenetic diversity of members of previously uncultivated epsilon-Proteobacteria in deep-sea hydrothermal fields. FEMS Microbiol Lett 218:167-174

Takai K, Gamo T, Tsunogai U, Nakayama N, Hirayama H, Nealson KH, Horikoshi K (2004) Geochemical and microbiological evidence for a hydrogen-based, hyperthermophilic subsurface lithoautotrophic microbial ecosystem (HyperSLiME) beneath an active deep-sea hydrothermal field. Extremophiles 8:269-282

Takai K, Nakagawa S, Reysenbach AL, Hoek J (2006) Microbial ecology of mid-ocean ridges and back-arc basins. In: Christie DM, Fisher CR, Lee SM, Givens S (eds) Back-arc spreading systems: geological, biological, chemical and physical interactions, vol 166, Geophysics monograph series. AGU, Washington, DC, pp 185-213

Takai K, Nunoura T, Ishibashi J, Lupton J, Suzuki R, Hamasaki H, Ueno Y, Kawagucci S, Gamo T, Suzuki Y, Hirayama H, Horikoshi $\mathrm{K}$ (2008) Variability in the microbial communities and hydrothermal fluid chemistry at the newly-discovered Mariner hydrothermal field, southern Lau Basin. J Geophys Res 113, G02031

Takai K, Nunoura T, Horikoshi K, Shibuya T, Nakamura K, Suzuki Y, Stott M, Massoth GJ, Christenson BW, de Ronde CEJ, Butterfield DA, Ishibashi J, Lupton JE, Evans LJ (2009) Variability in microbial communities in black smoker chimneys at the NW caldera vent field, Brothers volcano, Kermadec arc. Geomicrobiol J 26:552-569

Von Damm KL (1995) Diffuse flow hydrothermal fluids from $9^{\circ} 50^{\prime} \mathrm{N}$ East Pacific rise: origin, evolution and biogeochemical controls. In: Humphris SE, Zierenberg RA, Mullineaux LS, Thomson RE (eds) Seafloor hydrothermal systems, vol 144, Geophysics monograph series. AGU, Washington, DC 